\title{
Analysis of land use change and its relation to land potential and elephant habitat at Besitang Watershed, North Sumatra, Indonesia
}

\author{
WANDA KUSWANDA ${ }^{1,2, \boldsymbol{v}}$, AHMAD DANY SUNANDAR ${ }^{1}$ \\ ${ }^{1}$ Environment and Forestry Research and Development Center Aek Nauli, Jl. Raya Parapat 10.5, Parapat, Simalungun 21174, North Sumatera, Indonesia. \\ Tel.: +62-625-4559158, `email: wkuswan@yahoo.com; bpk.aeknauli@gmail.com \\ ${ }^{2}$ Program of Natural Resources and Environmental Management, School of Graduates, Universitas Sumatera Utara. Medan 20155, Sumatera Utara, \\ Indonesia
}

Manuscript received: 23 October 2018. Revision accepted: 30 December 2018

\begin{abstract}
Kuswanda W, Sunandar AD. 2019. Analysis of land use change and its relation to land potential and elephant habitat at Besitang Watershed, North Sumatra, Indonesia. Biodiversitas 20: 350-358. Land use change from forest into plantation at a watershed could be detrimental both for humans and wildlife. This study was aimed to analyze land use change and its impact on the habitat potential of Sumatran elephant (Elephas maximus sumatranus Temminck, 1857) in the upstream of Besitang Watershed located at Gunung Leuser National Park (GLNP), North Sumatra, Indonesia. The study was conducted from April to November 2015. Data collection was made through land cover map analysis, ground check and vegetation analysis using strip transect method. Land use change was analyzed using ArcView 3.2 software, species diversity was calculated using Shannon-Weiner formula and community evenness indices. Based on map delineation, total extent of Besitang Watershed is about 95,428 hectares. The analysis results showed that, in the past 25 years, about 15,989 hectares of land was changed from forests and farms to monoculture plantations. These changes have caused conflicts and threatened elephant population. As many as 168 species of plants were identified during vegetation analysis in the three study locations, namely Bukit Mas primary forest (88 species), Sekundur mixed secondary forest (91 species) and Halaban secondary forest (68 species). Average Importance Value Index (IVI) was below 40\% which indicates that there are no dominant plant species. Tree density was between 360 and 497,5 individual/ha, sapling density was between 2,640 and 4,680 individual/ha, and density of seedling and understory plants was between 27,750 and 38,500 individual/ha. Species diversity index for each plant growth stage was relatively high $\left(\mathrm{H}^{\prime}>3\right)$ and the similarity of plant species across locations was generally low (IS $\left.=<50 \%\right)$. Analysis of the correlation between land cover differences and habitat features showed statistically significant effects on species density and frequency. The highest effect of land cover change is on species density with the correlation reaching 94.5\%. Forests in GLNP will be able to regenerate naturally to reach a stable state if there is no more land clearing to raise plantations.
\end{abstract}

Keywords: Elephant, Gunung Leuser National Park, important value index land cover change,, species diversity

\section{INTRODUCTION}

Large-scale commercial logging and agro-industrial development were the main causes of deforestation in Sumatra during the last decade. During the last 20 year period between 1990 and 2010, around 7 million hectares of primary forest) and 33\% of degraded forest area were lost in Sumatra (Margono et al. 2012). Most of deforestation took place in lowland forests of Southern and Central Sumatra. In comparison, forest conditions in Aceh Province is much better at least until recently (Cochard 2016). The Leuser Ecosystem is however increasingly threatened by infrastructure development (Sloan et al. 2018). Since the Leuser ecosystem is in the upstream part of Besitang Watershed, any changes in this ecosystem will affect the downstream area.

According to Government Regulation No. 37 of 2012 concerning Watershed Management, a watershed area is a unified ecosystem unit, from upstream to downstream, consisting of land, vegetation, water, and air as main elements, and it has an important role in the sustainable economic development of the community in. Watershed area is currently one of the most priority natural ecosystems to protect. Protection of watershed ecosystems, which are currently becoming more critical, is considered as very important because it has role in many environmental services that are vital to human life, (Zhang et al. 2011; Daye and Healey 2015).

Watershed areas are currently being degraded due to increase human population (Kusumandari and Nugroho 2015). The carrying capacity of forest areas existing in watershed has decreased which is reflected in the frequent occurrence of floods, droughts, landslides and increase in critical land, including conservation forests (Paimin et al. 2012). Damage to conservation forests and protected forests which are generally located at the upstream of the watershed has caused the disruption of hydrological cycle (de Paula et al. 2015) and also increased habitat fragmentation affecting endangered species of wildlife (Corlett 2011). Conversion of forest land into agricultural land or plantations has resulted in fragmentation of remaining forests into smaller habitats (Numata et al. 2017). Globally, habitat loss due to changes in land use is the biggest threat to biodiversity (Martinuzzi et al. 2015). Change in land use is an effort to increase the economic value of land through production of plantation crops, 
agriculture or housing, but on the other hand, it reduces ecosystem services and biodiversity (Lawler et al. 2014). Besitang Watershed the upstream of which is located in Gunung Leuser National Park, North Sumatra, presents a similar situation.

Though, Besitang Watershed has been designated as one of the priority watersheds, in accordance with a circular issued by the Ministry of Forestry in 2009, forest degradation is still occurring in the upstream areas. Animal habitats in the upstream part of the Besitang Watershed continues to decrease and fragmented due to various causes such as plantation development, forest encroachment, and expansion of agricultural land. These developments have negative impacts on animal population in the area, as identified in case of population of elephants (Leuser 2009). Loss of habitat and declining quality of elephant habitat are serious threats to their reproductive capacity. Sumatran elephants (Elephas maximus sumatranus Temminck, 1847) which have both ecological and cultural importance, like Asian elephants in other regions, are increasingly threatened in their own territory due to habitat loss, conflict with humans and ivory trade (Jathanna et al. 2015). The population of Sumatran elephants is estimated to have decreased by approximately 35\% since 1992 (Supartono 2007). According to another report, $65 \%$ of the population of Sumatran elephants disappeared due to conflict with and killing by humans (Ministry of Forestry 2007). Further, these highly threatened animals may become extinct if there is no effort to improve its habitat conditions (Ministry of Forestry 2007). To support conservation effort, it is also critical to understand the impact of future land use change on wildlife habitat loss (Martinuzzi et al. 2015). Research on land use change and habitat carrying capacity could be a starting point to predict their probable impacts on animals and their conservation strategies.
Land conditions and elephant habitat in the upper reaches of the Besitang Watershed are currently unknown. This information is very important to improve the quality and strategy of elephant habitat management. This study aims to analyze changes in land cover and its relationship with the potential of land and elephant habitat in the upper reaches of the Besitang Watershed area, Gunung Leuser National Park, North Sumatra, Indonesia.

\section{MATERIALS AND METHODS}

\section{Study area}

This research was carried out in in the upstream and middle parts of Besitang Watershed, North Sumatra, Indonesia. This is part of the Gunung Leuser National Park (GLNP) and its buffer zone in Langkat Regency, North Sumatra, as shown in Figure 1.

Total extent of Besitang Watershed is estimated to be 98,702 ha of which around 14,324 ha is currently in critical condition due to the rampant timber theft and land encroachment for developing plantations (Sofyan in Waspada daily 2014). The upstream part of the Besitang Watershed is in the GLNP area which is a conservation forest, an area intended for protection and preservation of biodiversity as well as supporting community life. The GLNP region was stipulated based on the Decree of the Minister of Forestry number: 276 / Kpts-II / 1997 concerning the establishment of GLNP, covering an area of 1,094,692 ha in the Special Province of Aceh and North Sumatra. Geographically, the coordinates are $96^{\circ} 35^{\prime \prime}-98^{\circ}$ $30 "$ EL and $2^{\circ} 50$ "-4 10" NL (GLNP Institute 2009). The study was conducted for eight months from April to November 2015.


Figure 1. Research location in Besitang Watershed area of the Gunung Leuser National Park, North Sumatra, Indonesia 
Vegetation in GLNP region includes Sumatran flora and are closely related to flora in Peninsular Malaysia, Kalimantan Island, Java and even the Philippines (GLNP 2009). The GLNP region is also habitat for mammals, birds, reptiles, amphibians, fishes, and invertebrates. There are 380 species of birds and 129 species of large and small mammals have been found occurring in this area (GLNP 2009). Rare species found in GLNP includes Sumatran elephants (Elephas maximus sumatranus), Sumatran tigers (Panthera tigris sumatrae), Sumatran rhinos (Dicerorhinus sumatrensis), Sumatran orangutan (Pongo abelii), Siamang (Hylobates syndactylus) and Gibbons (Hylobates lar) (GLNP 2009).

Research plots to study habitat potential were selected in various dominant types of land cover of the study area, as follows: (i) Observation location in Bukit Mas area, covering primary forest land cover (towards Senapal village), located between $03^{\circ} 57^{\prime} 54.4$ "NL and $98^{\circ} 04^{\prime} 53.5^{\prime \prime}$ EL, and $03^{\circ} 58^{\prime} 04.4^{\prime \prime} \mathrm{NL}$ and $98^{\circ} 04$ '42.9 " EL with altitude range of 60-200 meters above sea level; (ii) Observation location in the Sekundur/Gunung Putri area includes land cover of mixed old and young secondary forests located between $03^{\circ} 57$ ' $13.7^{\prime \prime} \mathrm{NL}$ and $98^{\circ} 04^{\prime} 38.6^{\prime \prime} \mathrm{EL}$, and $03^{\circ} 57$ '29.2 " NL and $98^{\circ} 04$ '36.1" EL with altitude range of 70150 meters above sea level; (iii) Observation location in Halaban Region, covering old secondary forest land cover, located between $04^{\circ} 01$ '46.3" NL and 98 $03^{\circ}$ ' 24.4" EL, and $04^{\circ} 01$ '38.6 " NL and $98^{\circ} 03^{\prime}$ ' 22.3" EL with altitude range of 80-100 meters above sea level (Figure 2.).

\section{Data collection}

\section{Land cover}

Land cover change data of Besitang Watershed was collected by analysis of land cover maps issued by the Forestry Planning Agency for the years 1990 and 2014. Others such as administrative maps, watershed boundary maps, and forest area maps were also used to complete land cover analysis. Presently existing land cover of the study area was determined by ground checking along the Besitang River (from the middle to upstream), starting from Bukit Mas Village (buffer village) towards the research station at Sikundur (Sei Betung Resort, Gunung Leuser National Park Area). Furthermore, ground checking and descriptive observations were carried out to determine the current land cover conditions in each existing land cover class based on maps, especially in the upper and middle parts of the Besitang Watershed. The selection of the ground checking locations is done by search sampling, especially around the Besitang River. The length of the ground checking line was $6 \mathrm{~km}$.

\section{Elephant habitat potential}

Data regarding habitat potential were collected by constructing vegetation analysis plots according to the strip transect method around the elephant track and feeding locations (Kusmana 1997; Amjad et al. 2014). The observation plots were chosen by stratification based on differences in dominant land cover, namely primary and secondary forests. The total number of plots were 30 and total area covered by observation plots is 1.2 ha. Trees were observed with plots measuring $20 \mathrm{~m}$ x $20 \mathrm{~m}$, saplings with $5 \mathrm{~m} \mathrm{x} 5 \mathrm{~m}$ plots, and seedlings and understories in $2 \mathrm{~m}$ x $2 \mathrm{~m}$ plots(Irwan 2007; Mandal and Joshi 2014). The information collected was name of the plant species and number of individuals of each species, for seedling and understorey/sapling levels. For trees, name of species, number of individuals of each species and diameter at breast height were recorded (Kuswanda and Kwatrina 2010; Alatar et al. 2012; Sathish et al. 2013). Botanical identification of plants was carried out in Botanical Laboratory, Forest Research and Development Center, Ministry of Environment and Forestry.

\section{Data analysis}

Dominant land cover analysis was carried out through interpretation of various maps using ArcView software and descriptive analysis of the results of ground checkings in the field. Map analysis was focused on finding out changes in land cover in the last 25 years (1990 to 2014). Plant composition in each study location was analyzed based on the important value index (IVI) of each plant species. The IVI is the sum of the Relative Dominance, Relative Density and Relative Frequency for the tree level plants and the sum of the Relative Density and Relative Frequency only, for saplings and seedlings/understories (Greig-Smith 1983; Mandal and Joshi 2014).

Vegetation diversity was analyzed by Shannon and Weiner index (Sathish et al. 2013; Alatar et al. 2012). The abundance of plant species in a community (forest cover) was calculated by Hill formula (1973). Sorensen Community Similarity Index (IS) was calculated to find out the similarity between elephant habitat types. The criteria used were high if the IS value is $>50 \%$ and low if the IS value is $<50 \%$ (Mueller-Dumbois and Ellenberg 1974; Odum 1998).

Analysis of land use changes in relationship to plant density conditions, diversity index, similarity of plants and the number of plant species based on growth classification (seedlings, saplings, and trees) was carried out using Spearman's rho correlation test. According to Ghozali (2009), the Spearman correlation test can be used in a small sample population and does not require the assumption that data is spread normally and data is measured in the form of ranks. Data analysis was done using SPPS for Windows version 17

\section{RESULTS AND DISCUSSION}

\section{Land use types and changes}

Based on the results of map analysis, land covers in the upstream (GLNP area) and center part of the watershed are generally primary and secondary forests, plantations and agricultural land. Land cover in the form of primary and secondary forests still exists in the upstream to the middle of Besitang Watershed, which is GLNP area. Another dominant land use that currently exist is plantations which is dominated by oil palm, rubber and citrus plantations, 
especially from the middle part to the downstream. According to the National Park Office of Gunung Leuser (2009), national park forest area at Region VI of the Besitang Management Section having an area of 28,688 ha has been divided into pieces by oil palm plantations so that several locations of animal habitats have become fragmented.

Comparison of land cover maps showed that in the interval of 25 years, there have been considerable changes in land cover in the Besitang Watershed, upstream and middle, especially from primary and secondary forests to plantations (Figure 2). Land changes from primary and secondary forest that occurred during the last 25 years reached almost 4,000 ha $(4.2 \%)$. This proved that there has been a very high rate of clearing of forests to be used for raising plantations and developing as settlement areas. Other significantly reduced land use types are agricultural land and shrubs which together shrunk by almost 11,600 ha which most likely changed into plantations (Table 1).


Figure 3. Land change maps in the Besitang Watershed from 1990 (left) and 2014 (right), Gunung Leuser National Park, North Sumatra, Indonesia

Table 1. Changes in land use in the Besitang Watershed from 1990 to 2014, Gunung Leuser National Park, North Sumatra, Indonesia

\begin{tabular}{|c|c|c|c|c|c|c|}
\hline \multirow{2}{*}{ Land use classifications } & \multicolumn{4}{|c|}{ Year (ha) } & \multirow{2}{*}{$\begin{array}{l}\text { Changes } \\
1990-2014\end{array}$} & \multirow{2}{*}{ Remarks } \\
\hline & 1990 & 2000 & 2011 & 2014 & & \\
\hline Swamp shrubs & 364 & 354 & 347 & 347 & 17 & Reduced \\
\hline Primary Dryland Forest & 35.298 & $34 . .253$ & 34.253 & 34.147 & 1.151 & Reduced \\
\hline Secondary Dryland Forest & 4.059 & 2.481 & 1.282 & 1.238 & 2.821 & Reduced \\
\hline Primary Mangrove Forest & 813 & 0 & 0 & 0 & 813 & Lost completely \\
\hline Secondary Mangrove Forest & 7.454 & 5.911 & 4.085 & 3.876 & 3.578 & Reduced \\
\hline Settlement & 159 & 169 & 169 & 169 & $(10)$ & Increased \\
\hline Plantation & 10.078 & 14.542 & 26.067 & 26.067 & $(15.989)$ & Increased \\
\hline Mining & 2 & 2 & 2 & 2 & - & Stable \\
\hline Dryland Agriculture & 13.634 & 16.981 & 5.973 & 5.973 & 7.661 & Reduced \\
\hline Agriculture of Mixed shrubs & 3.956 & 3.793 & 15 & 15 & 3.941 & Reduced \\
\hline Swamp & 0 & 9 & 9 & 9 & (9) & Increased \\
\hline Rice fields & 1.977 & 815 & 2.088 & 2.088 & (111) & Increase \\
\hline Shrubs & 14.851 & 11.034 & 13.969 & 14.017 & 834 & Reduced \\
\hline Fishpond & 1.067 & 3.141 & 3.484 & 3.484 & $(2.417)$ & Increased \\
\hline Open Land & 365 & 592 & 2.334 & 2.645 & $(2.280)$ & Increased \\
\hline Water Body (river/lake) & 755 & 755 & 755 & 755 & 0 & Stable \\
\hline No data & 455 & 455 & 455 & 455 & 0 & Stable \\
\hline Total & 94.832 & 94.832 & 94.832 & 94.832 & & \\
\hline
\end{tabular}


The results of the ground check at Sei Betung Resort (upstream part of Besitang Watershed) showed that the condition of primary and secondary forests was relatively good and well maintained. Since forest concessions had stopped in the middle of 1980s, there were no encroachments or forest openings by the community. Some of the dominant tree species encountered include Shorea atrinevosa, Hopea sangal, Shorea inapendiculata, Parashorea glubosa, Shorea leprosula, Shorea acuminata, Shorea parvifolia and Shorea dasyphylla, Quercus spp, Palaquium obovatum and Eugenia fastigata.

Results of ground check along the Besitang River (from the middle to upstream) showed that the conditions in the central part were of mixed nature because some areas still remain forested and some of them have been changed into plantations and residential areas. This area was thought to be prone to land conflicts because it is directly adjacent to the GLNP area and land clearing is still occurring, thus land use in this area is more dynamic. In addition, there are also some elephant tracks in this area, especially towards Aras Napal village and near the Elephant Patrol Unit (UPG). In the area of the UPG, citrus plantations are more commonly found till the border of GLNP and other tree types that are found include Eugenia fastigata, Macaranga sp. and Alstonia scholaris. Citrus plantation was found until the border of GLNP.

According to Paimin (2009), as an ecosystem, a watershed is a management unit because every input can be evaluated by looking at the outputs of the ecosystem. Government should maintain sufficiency of area and forest cover of any watershed to optimize the environmental, social and economic benefits to the community. Notohadiprawiro (1981) and Bhan (2013) previously stated that one of the principles in watershed management is the management of watershed natural resource assets that have conservation values. There are three approaches in its application, which are preservation of environmental functions, benefits of employers or companies shifted to social benefits and sustainability of production shifted to the preservation of ecosystems.

It is very important to consider integration between upstream, middle and downstream areas, in the management of a watershed (Paimin et al. 2012). Any changes in land use in the upstream areas will impact the downstream areas, in the form of fluctuations in water flow, water quality and transport of sediments and dissolved materials. In order to maintain a stable hydrological cycle, the forest areas in the upstream must be maintained in optimal conditions, so that they are able to regulate surface water runoff, interflow and groundwater flow (Sriharto 1993).

\section{Habitat potential \\ Vegetation composition}

The results of vegetation analysis in the three observation sites revealed that there were a total of 168 plant species growing in these sites. Detailed results of analysis conducted in each research site is provided further.

Site 1: Primary forest of Bukit Mas. In the Bukit Mas region, 88 plant species were identified in primary forest cover, including 63 species of trees, 30 species of saplings and 36 species of seedlings/understory. Result of IVI analysis for the top three dominant plant species in each life form stage (trees, saplings, and seedlings), can be seen in Table 2.

Site 2: Mixture of old and young secondary forests of Sekundur Area. In the mixture of old and young secondary forests of the Sekundur area, 91 species of plants were recorded which included 58 species of trees, 37 species of saplings, and 37 species of seedlings and understory plants. Result of IVI analysis for top 3 dominant plant species in each level is provided in Table 3.

Site 3: Old secondary forest of Halaban Area. In old secondary forest of Halaban area, 68 plant species were identified consisting of 41 species of trees, 29 species of saplings and 32 species of seedling and understory plants. Results of IVI analysis of three dominant species can be seen in Table 4. IVI analysis result showed that at tree level, the most dominant was Dipterocarpus kunstleri (IVI $=42.30 \%$ ), at sapling level, the most dominant was Litsea brachystachys $($ IVI $=19.30 \%)$ and at seedling level was Lasianthus constrictus (IVI $=19.45 \%$ ). This elephant habitat area is adjacent to the location of the Orangutan Information Center (OIC) and previously it was a community plantation area ( oil palm plantation) and illegal logging area.

Table 2. The important value index (IVI) of three species dominant in the primary forest of Bukit Mas study site in the Besitang Watershed, Gunung Leuser National Park, North Sumatra, Indonesia

\begin{tabular}{|c|c|c|c|c|c|c|}
\hline Level of vegetation & Scientific name & Family & $\begin{array}{l}\text { RD } \\
(\%)\end{array}$ & $\begin{array}{l}\text { RF } \\
(\%)\end{array}$ & $\begin{array}{c}\text { RDe } \\
(\%)\end{array}$ & $\begin{array}{c}\text { IVI } \\
(\%)\end{array}$ \\
\hline \multirow[t]{3}{*}{ Tree } & Baeckea frutescens & Euphorbiaceae & 12.25 & 5.04 & 4.31 & 21.60 \\
\hline & Payena sericea & Sapotaceae & 4.23 & 5.04 & 3.45 & 12.71 \\
\hline & Shorea leprosula & Dipterocarpaceae & 5.18 & 2.88 & 3.45 & 11.51 \\
\hline \multirow[t]{3}{*}{ Sapling } & Castanopsis rhamifolia & Fagaceae & 11.83 & 8.62 & - & 20.45 \\
\hline & Lasianthus constrictus & Euphorbiaceae & 9.86 & 8.62 & - & 18.30 \\
\hline & Cinnamomum cuspidatum & Lauraceae & 6.45 & 6.90 & - & 13.35 \\
\hline \multirow{2}{*}{ Seedling and under story } & Lasianthus constrictus & Euphorbiaceae & 6.25 & 6.35 & - & 12.60 \\
\hline & Cinnamomum cuspidatum & Lauraceae & 24.41 & 7.94 & - & 32.35 \\
\hline
\end{tabular}

Note :-= Not analyzed, RD = Relative dominance, RDe = Relative density, RF = Relative frequency, IVI =Importance Value Index 
Table 3. The important value index of three species dominant in the mixture of old and young secondary forests of Sekundur area in the Besitang Watershed, Gunung Leuser National Park, North Sumatra, Indonesia

\begin{tabular}{lllcccc}
\hline Level of vegetation & \multicolumn{1}{c}{ Scientific name } & Family & $\begin{array}{c}\text { RD } \\
(\boldsymbol{\%})\end{array}$ & $\begin{array}{c}\text { RF } \\
(\boldsymbol{\%})\end{array}$ & $\begin{array}{c}\text { RDe } \\
(\boldsymbol{\%})\end{array}$ & $\begin{array}{c}\text { IVI } \\
(\boldsymbol{\%})\end{array}$ \\
\hline Tree & Macaranga hypoleuca & Euphorbiaceae & 7.77 & 16.08 & 4.59 & 28.43 \\
& Macaranga gigantea & Euphorbiaceae & 7.34 & 13.57 & 6.42 & 27.33 \\
\multirow{5}{*}{ Sapling } & Instia bijuga & Mimosasae & 5.10 & 4.52 & 4.59 & 14.21 \\
& Cryptocarya nitens & Lauraceae & 7.69 & 6.15 & - & 13.85 \\
\multirow{5}{*}{ Seedling and under stories } & Lasianthus constrictus & Euphorbiaceae & 7.69 & 6.15 & - & 13.85 \\
& Parashorea sp. & Dipterocarpaceae & 7.69 & 4.62 & - & 12.31 \\
& Asplenium minus & Polypodiaceae & 9.09 & 9.38 & - & 18.47 \\
& Vitis gracilis & Vitaceae & 6.49 & 4.69 & - & 11.18 \\
\hline
\end{tabular}

Note :-= Not analyzed, RD = Relative dominancy, RDe $=$ Relative density, RF $=$ Relative frequency and IVI =Importance value index

Table 4. The important value index of three species dominant in the old secondary forests of Halaban area in the Besitang Watershed, Gunung Leuser National Park, North Sumatra, Indonesia

\begin{tabular}{lllcccc}
\hline \multicolumn{1}{c}{ Level of vegetation } & \multicolumn{1}{c}{ Scientific name } & Family & $\begin{array}{c}\text { RD } \\
(\boldsymbol{\%})\end{array}$ & $\begin{array}{c}\text { RF } \\
(\boldsymbol{\%})\end{array}$ & $\begin{array}{c}\text { RDe } \\
(\boldsymbol{\%})\end{array}$ & $\begin{array}{c}\text { IVI } \\
(\boldsymbol{\%})\end{array}$ \\
\hline \multirow{2}{*}{ Tree } & Dipterocarpus kunstleri & Dipterocarpaceae & 21.99 & 11.81 & 8.51 & 42.30 \\
& Pometia tomentosa & Sapindaceae & 13.25 & 5.56 & 5.32 & 24.12 \\
& Quercus sp. & Fagaceae & 8.61 & 6.25 & 5.32 & 20.18 \\
Sapling & Litsea brachystachys & Lauraceae & 10.61 & 8.70 & - & 19.30 \\
& Mastixia trichotoma & Cornaceae & 9.09 & 6.52 & - & 15.61 \\
& Cinnamomum subavenium & Lauraceae & 7.58 & 6.52 & - & 14.10 \\
Seedling and under stories & Lasianthus constrictus & Euphorbiaceae & 10.68 & 8.77 & - & 19.45 \\
& Cinnamomum subavenium & Lauraceae & 7.77 & 7.02 & - & 14.78 \\
& Litsea brachystachys & Lauraceae & 5.83 & 7.02 & - \\
\hline
\end{tabular}

Vegetation analysis in three study locations indicated that the dominant plant species are different in all sites and at all levels of vegetation. The most dominant species at saplings level is not the most dominant at tree level or seedling level. The maximum number of plant species was found in a mixture of old and young secondary forests of Sekundur region. Mixed forests generally have a higher diversity of plant species than primary forests (Odum 1998). In young secondary forests at Halaban and Sekundur areas, pioneer species such as Macaranga sp. were still found.

The difference in the dominant species at each growth level indicated that several species do not grow fully to reach the tree level which may be caused by losing in competition or death during natural regeneration process, especially in primary forest areas. However, species from the Dipterocarpaceae and Euphorbiaceae families were found to be dominant in almost every level of growth. Research sites which are generally lowland forests $(<400$ meters above sea level) are considered to have climate and soil conditions that are suitable for the growth of members of these families (Reddy et al. 2011; Reddy et al. 2013; Amjad et al. 2014).

\section{Density and diversity index}

The results of density, abundance and plant species diversity analysis in each study location is presented in Table 5. Vegetation density at all growth level in each study location was relatively high. The results showed that tree density was between 360 and 497.5 individuals/ha, sapling density was between 2.640 and-4.680 individuals/ha, and seedling and under story density was between 27,750 and 38,500 individuals/ha The large number of pioneer plants which are still regenerating as well as other plants resulted in higher density of plants at the sapling level in this location compared to other research locations.

Analysis of diversity and abundance indices also showed that Sekundur area has a higher value than other locations. High value of species diversity for each growth rate $\left(\mathrm{H}^{\prime}>3\right)$ indicated that secondary and primary forest areas around the Besitang Watershed, especially in GLNP area, will regenerate until it reaches the climax forest when there are no natural disturbances or human activities which will turn the forest area into plantation land. Human activities, such as encroachment and illegal logging, will affect diversity and species regeneration in a habitat (Sathis et al. 2013; Amjad et al. 2014).

Fodder plants for elephants were present in quite high number, especially in the Bukit Mas area. There were about 25 species of elephant fodder plants in $1.5 \mathrm{~km}$ stretch of observatory track at GLNP which was guided by trained elephants in UPG. Fodder trees present were Palaqium gutta Eugenia glandiflora, Spondias pinnata and Nephelium mutabile while in seddling and understorey levels were Asplenium minus, Chrysopogon aciculata, Axonopus compresus, Mimosa pudica and Selaginella muricata. 
Table 5. Density, abundance, and plant species diversity index at different study locations in the Besitang Watershed, Gunung Leuser National Park, North Sumatra, Indonesia

\begin{tabular}{llccc}
\hline Area & Tingkat & Density (ind./ha) & Species diversity & Species abundance \\
\hline Halaban & Seedling and under story & $25,750.0$ & 3.25 & 35.50 \\
& Sapling & $2,640.0$ & 3.22 & 32.43 \\
\multirow{4}{*}{ Bukit Mas } & 360.0 & 3.33 & 44.54 \\
& Tree & $32,000.0$ & 3.38 & 39.58 \\
& Seedling and under story & $3,720.0$ & 3.20 & 33.42 \\
& Sapling & 347.5 & 3.92 & 67.08 \\
& Tree & $38,500.0$ & 3.41 & 40.61 \\
& Seedling and under story & $4,680.0$ & 3.46 & 40.65 \\
& Sapling & 497.5 & 3.77 & 62.94 \\
\hline
\end{tabular}

Result of vegetation composition and species diversity analysis showed that this watershed area is very much suitable for elephant habitat. The threat of elephants around the Besitang Watershed is due to the rampant land clearing to raise oil palm plantations. This activity has an impact on elephant populations as they get disturbed because their pathways and foraging places are lost (Leimgruber et al. 2003).

\section{Vegetation similarity between habitat types}

Sorensen Community Similarity Index (Muller-Dombas and Ellenberg 1974) was applied to find out the similarity among plant communities of the study sites. The results of such an analysis of vegetation similarity among study locations can be seen in Table 6 .

It is apparent that almost all study sites have low similarity values, which were below $50 \%$ on an average, except between Bukit Mas primary forest and Sekundur secondary forest which showed similarity above $50 \%$. Similarity values below $50 \%$ indicated that there are significant differences in plant structure at various levels of growth. Differences in vegetation types are possible because of the impact of deforestation, especially in young secondary forests, plant adaptation processes and soil fertility (de Paula et al. 2015).

The difference in plant composition in each location will certainly support elephant growth. As herbivorous animals, elephants tend to certainly choose the habitat that provides the maximum food needs. In addition, elephants especially need plant leaves which contain calcium minerals to strengthen bones, teeth, and ivory. The fodder need of elephants is about $200-300 \mathrm{~kg}$ of biomass per day for each adult elephant (Hutwan 2008).

\section{Effect of land cover on habitat potential}

The impact of differences of land cover on the various habitat features such as density, frequency, species diversity, and species similarity was analyzed by employing Spearman's rank correlation technique and the results are provided in Table 7 . The results showed that land cover differences significantly affect species density and frequency, with sig. values $<0.05$. The highest effect of land cover change is on species density with the correlation reaching $94.5 \%$. According to Ellis-Cockcroft and Cotter (2014) and Riutta et al. (2014), logging and clearing of forests will have a fragmentation impact on forests with reduction of plant density, including elephant fodder. The relationship of land cover changes to the diversity value and species abundance was not significant ( $\mathrm{sig}>0.05)$. The value of diversity and abundance of species is significantly low because this study was carried out in primary forest on one side and secondary forests on the other side.

Table 6. Similarity index between different habitats

\begin{tabular}{lccc}
\hline \multirow{2}{*}{ Habitat locations } & \multicolumn{3}{c}{ Similarity index(\%) } \\
\cline { 2 - 4 } & Bukit Mas & Sekundur & Halaban \\
\hline Bukit Mas & - & 52.51 & 24.36 \\
Sekundur & 52.51 & - & 26.42 \\
Halaban & 24.36 & 26.42 & - \\
\hline
\end{tabular}

Table 7. Correlation between land cover and density, frequency, species diversity, and species similarity

\begin{tabular}{|c|c|c|c|c|c|c|}
\hline & & $\begin{array}{l}\text { Land } \\
\text { cover }\end{array}$ & Density & Frequency & $\begin{array}{c}\text { Species } \\
\text { diversity }\end{array}$ & $\begin{array}{c}\text { Species } \\
\text { Similarity }\end{array}$ \\
\hline \multirow{3}{*}{ Spearman's rho } & Correlation Coefficient & 1.000 & $-.949^{* * *}$ & $.685^{*}$ & .369 & .632 \\
\hline & Land coverSig. (2-tailed) & . & .000 & .042 & .329 & .068 \\
\hline & $\mathrm{N}$ & 9 & 9 & 9 & 9 & 9 \\
\hline
\end{tabular}




\section{Discussion}

Dominant land use type in the upstream and middle part of Besitang Watershed was primary forest $(34,147$ ha), secondary forest $(2,821 \mathrm{ha})$ and plantations. Forest and agriculture land change into plantations in the last 25 years reached 15,989 ha. The dominant plantations around Besitang Watershed were oil palm and oranges. Conversion of forest into plantations have resulted in habitat fragmentation and the breakdown of elephant trajectories leading to frequent elephant-human conflicts. The decrease in forest area directly reduced the habitat availability for Asian elephants and the resultant habitat destruction and fragmentation also affected their migration, causing more farmland invasions and human-elephant conflicts/HECs (Lin et al. 2015; Chen et al. 2016).

Changing land cover from forests into plantation land needs serious attention (de Paula et al. 2015). This is because a forested land also functions as wildlife habitat and range for various types of endangered and protected animals that have high ecological and conservation values (Abdullah et al. 2015). The plantations with monoculture species, such as oil palm plantations, tends to have a negative impact on animal life. Land opening for oil palm plantations caused forest loss and their fragmentation into smaller areas which are separated from each other. Forest trees are source of food and also serve as their dwelling and breeding places. There are many wildlife species such as primates from the Hylobatidae and Pongidae groups, birds from the Bucerotidae group (hornbill groups), and birds that live in tree holes such as parrots, which depend on trees most of their lives (Kuswanda and Kwatrina 2010). That functional diversity of birds experiences severe decline along a gradient from unlogged forest to logged forest to oil palm (Azhar et al. 2013; Edwards et al. 2013). The diversity and abundance of birds and even elephants decreases after the opening of forests to oil palm plantations (Teuscher et al. 2015; Evans et al.2018).

Plantation development will also be followed by the development of infrastructure, such as road networks, settlements, processing plants, and other economic activities. The formation of roads will make it easier for anyone to access more forest areas around oil palm plantations, thus forest areas will continue to decrease. The impact will be greater when plantation area is located adjacent to conservation forests area, especially those that function as wildlife preservation, such as national parks (Kuswanda and Kwatrina 2010).

Former encroachment areas were found during observation in GLNP They were carried out by local people around the national park. Some of this areas have become barren land which are now covered by resam (ferns) and shrubs. Other undisturbed areas have become secondary forests which are in relatively good condition, especially in the border of the UPG area. In other observation locations around Sekundur research station, there are several tree species which are encountered in lowland forest types, such as Parashore glubosa, Shorea leprosula, Shorea acuminata, Shora parvifolia, Shorea dasyphylla and Palaquim sp.
The forest in the GLNP region is suitable for elephant habitat because it has high seedling and sapling plant density and provides various types of fodder sources. 168 species of plants were identified in total, including 88 species from Bukit Mas primary forest, 91 from Sekundur mixed secondary forest and 68 species from Halaban secondary forest. The dominant species include mata rusa (Baeckea frutescens Linn), karakas (Castanopsis rhamifolia (Miq.) Dc.), Keruing (Dipterocarpus kunstleri King) and rambutan hutan (Cryptocrya nitens (Blume) Koord. \& Val.). Land in low elevation area has also been shown to be of crucial importance as elephant habitat. Therefore, it is crucially important that remaining lowstature forest in these areas are protected. The combination of both short-stature forest and low-lying flatlands produce highly suitable, energetically low habitat with plenty of feeding opportunities for elephants (Murtilaksono et al. 2011; Evans et al.2018).

\section{ACKNOWLEDGEMENTS}

Authors are grateful to the Head of Gunung Leuser National Park Office, Head of the North Sumatra KSDA Headquarters, Head of the Environment and Forestry Research and Development Center Aek Nauli, and also to Researchers and Technical Officers of these Institutions, for their help in licensing and conducting this research.

\section{REFERENCES}

Alatar A, El-Sheikh MA, Thomas J. 2012. Vegetation analysis of Wadi Al-Jufair, a hyper-arid region in Najd, Saudi Arabia. Saudi J Biol Sci 19 (1): 43-54

Bhan S. 2013. Land degradation and integrated watershed management in India. Intl Soil Water Conserv Res 1 (1): 49-57.

Cochard R. 2016. Scaling the Costs of Natural Ecosystem Degradation and Biodiversity Losses in Aceh Province, Sumatra. Redefining Diversity and Dynamics of Natural Resources Management in Asia Vol. 1. Elsevier, New York.

Corlett R. 2011. Impacts of warming on tropical lowland rainforests. Trends Ecol Evol 26 (11): 606-613.

Daye D, Healey J. 2015. Impacts of land-use change on sacred forests at the landscape scale. Global Ecol Conserv 3: 349-358.

de Paula M, Groeneveld J, Huth A. 2015. Tropical forest degradation and recovery in fragmented landscapes - Simulating changes in tree community, forest hydrology and carbon balance. Global Ecol Conserv 2 (3): 664-677.

GLNP. 2009. Rencana Pengelolaan Jangka Panjang Taman Nasional Gunung Leuser Periode 2010-2029 Propinsi Aceh dan Sumatera Utara. Balai Taman Nasional Gunung Leuser, Medan. [Indonesian]

Greig-Smith P. 1983. Quatitative Plant Ecology. Blackwell Scientific Publication, Oxford, UK.

Jathanna D, Karanth KU, Kumar NS, Goswami VR, Vasudev D, Karanth KK. 2015. Reliable monitoring of elephant populations in the forests of India: Analytical and practical considerations. Biol Conserv 187: 212-220.

Kusumandari A, Nugroho P. 2015. Land capability analysis based on hydrology and soil characteristics for watershed rehabilitation. Procedia Environ Sci 28: 142-147.

Kuswanda W, Kwatrina R. 2010. Strategi Konservasi Habitat satwaliar Langka pada Perkebunan Sawit. In Proseding Seminar Bersama "Peran Litbang Kehutanan dalam Implementasi RSPO". Puslitbang Hutan dan Konservasi Alam. Pekanbaru. [Indonesian] 
Leimgruber P, Gagnon JB, Wemmer C, Kelly DS, Songer MA, Selig ER. 2003. Fragmentation of Asia's remaining wildlands: Implications for Asian elephant conservation. Anim Conserv 6 (4): 347-359.

Leuser BTNG. 2009. Rencana Pengelolaan Jangka Panjang Taman Nasional Gunung Leiser Periode 2010-2029. Direktorat Jendera Perlindungan Hutan dan Konservasi Alam. Kementerian Kehutanan, Jakarta.

Mandal G, Joshi SP. 2014. Analysis of vegetation dynamics and phytodiversity from three dry deciduous forests of Doon Valley, Western Himalaya, India. J Asia-Pac Biodiv 7 (3): 292-304.

Margono B, Turubanova S, Zhuravleva I, Potapov P, Tyukavina A Baccini A, et al. 2012. Mapping and monitoring deforestation and forest degradation in Sumatra (Indonesia) using Landsat time series datasets from 1990 to 2010. Environ Res Lett 7: 034010. DOI $10.1088 / 1748-9326 / 7 / 3 / 034010$

Martinuzzi S, Withey JC, Pidgeon AM, Plantinga AJ, McKerrow AJ, Williams SG, et al. 2015. Future land-use scenarios and the loss of wildlife habitats in the southeastern United States. Ecol Appl 25 (1): 160-171.

Numata I, Silva SS, Cochrane MA, d'Oliveira MV. 2017. Fire and edge effects in a fragmented tropical forest landscape in the southwestern Amazon. For Ecol Manag 401: 135-146.

Paimin, Pramono I, Purwanto, Dewi R. 2012. Sistem Perencanaan Pengelolaan Daerah Aliran Sungai. Pusat Litbang Konservasi dan Rehabilitasi, Bogor. [Indonesian]
Reddy CS, Babar S, Amarnath G, Pattanaik C. 2011. Structure and floristic composition of tree stand in tropical forest in the Eastern Ghats of northern Andhra Pradesh, India. J For Res 22 (4): 491-500.

Reddy CS, Sreelekshmi S, Jha CS, Dadhwal VK. 2013. National assessment of forest fragmentation in India: Landscape indices as measures of the effects of fragmentation and forest cover change. Ecol Eng 60: 453-464.

Sathish B, Viswanath S, Kushalappa C, Al E. 2013. Comparative assessment of floristic structure, diversity and regeneration status of tropical rain forests of Western Ghats of Karnataka, India. J Appl Nat Sci 5: 157-164.

Sloan S, Campbell MJ, Alamgir M, Collier-Baker E, Nowak MG, Usher G, Laurance WF. 2018. Infrastructure development and contested forest governance threaten the Leuser Ecosystem, Indonesia. Land Use Pol 77: 298-309.

Supartono. 2007. Preferensi dan Pendugaan Produktivitas Pakan Alami Populasi Gajah Sumatera (Elephas maximus sumatranus Temmick, 1847) di Hutan Produksi Khusus (HPKh) Pusat Latihan Gajah (PLG) Sebelat Bengkulu Utara. Institut Pertanian Bogor, Bogor. [Indonesian]

Zhang T, Yan H, Shan J. 2011. Economic Valuation of Forest Ecosystem Services in Heshui Watershed using Contingent Valuation Method. The 18th Biennial Conference of International Society for Ecological Modelling. Procedia Environ Sci 8: 2471-2476. 